九州大学学術情報リポジトリ

Kyushu University Institutional Repository

\title{
Assessment of Environmental Impact for Air- Conditioning Systems in Japan Using HFC Based Refrigerants
}

Kibria, Mohammad Tawheed

Kyushu University Program for Leading Graduate School, Green Asia Education Center, Kyushu University

Is lam, Md. Amirul

Kyushu University Program for Leading Graduate School, Green Asia Education Center, Kyushu University

Saha, Bidyut Baran

Kyushu University Program for Leading Graduate School, Green Asia Education Center, Kyushu University

Nakagawa, Takeshi

Kyushu University Program for Leading Graduate School, Green Asia Education Center, Kyushu University

他

https://doi.org/10.5109/2349301

出版情報：Evergreen. 6 (3)，pp.246-253，2019-09. 九州大学グリーンテクノロジー研究教育センター バージョン：

権利関係 : 


\title{
Assessment of Environmental Impact for Air-Conditioning Systems in Japan Using HFC Based Refrigerants
}

\author{
Mohammad Tawheed Kibria',2,*, Md. Amirul Islam ${ }^{1,3}$, Bidyut Baran Saha ${ }^{1,3}$, \\ Takeshi Nakagawa ${ }^{1,2}$, Seigi Mizuno ${ }^{1,2}$ \\ ${ }^{1}$ Kyushu University Program for Leading Graduate School, Green Asia Education Center, \\ Kyushu University, Kasuga-Koen 6-1, Kasuga-Shi, Fukuoka 816-8580, Japan \\ ${ }^{2}$ Interdisiciplianry Graduate School of Engineering Sciences, Department of Molecular and Material Science, \\ Kyushu University, Kasuga-Koen 6-1, Kasuga-Shi, Fukuoka 816-8580, Japan \\ ${ }^{3}$ International Institute for Carbon-Neutral Energy Research (WPI-I ${ }^{2} \mathrm{CNER}$ ), Kyushu University, \\ 744 Motooka, Nishi-ku, Fukuoka 819-0395, Japan \\ *Author to whom correspondence should be addressed, \\ E-mail: kibria.tawheed@kyudai.jp
}

(Received April 12, 2019; accepted July 12, 2019).

\begin{abstract}
Air-conditioning system notably contributes to global warming owing to the huge amount of energy consumption. Moreover, this system uses HFC based refrigerants, which have high global warming potential (GWP). This work investigates the direct and indirect impacts of GWP for commercial and residential air-conditioning systems considering the three widely used HFC based refrigerants. The warming impacts are assessed in terms of cooling load, co-efficient of performance (COP), evaporation temperature, and condensation temperature for three different locations in Japan. The indirect emission of the air-conditioning systems (commercial and residential) for different major cities of Japan is estimated in terms of energy demand and hours of operation. The results of this work indicate that the HFC based refrigerants such as R134a and R32 have lower warming impact compared to that of R410A refrigerant. Furthermore, the economic loss due to refrigerant leakage is also assessed.
\end{abstract}

Keywords: Air-conditioning system; COP; GWP; HFC; TEWI.

\section{Introduction}

The air-conditioning systems have a significant impact on the residential and commercial usages for space heating and cooling requirements all over the year ${ }^{1-3)}$. The refrigerants used in the air-conditioning systems predominantly contribute to direct and indirect global warming impact ${ }^{2,45}$. The appropriate choice of the refrigerant is crucial for a minimum contribution to global warming. The refrigerants should have to fit with the following requirements: environmental acceptability, chemical stability, materials stability, refrigerationcycle performance, adherence to non-flammable and nontoxic guidelines, boiling and evaporation point, critical points ${ }^{6}$. For hundreds of years, Carbon dioxide $\left(\mathrm{CO}_{2}\right)$ is the prime candidate to contribute to greenhouse gases.

On the other hand, refrigerants based on chlorofluorocarbons (CFC), hydrochlorofluorocarbons (HCFC) and currently used hydrofluorocarbons (HFC) have much higher Global Warming Potential (GWP) than $\mathrm{CO}_{2}{ }^{2,4-6)}$. Moreover, this $\mathrm{CFC}$ and $\mathrm{HCFC}$ based refrigerants are responsible for ozone layer depletion (ODP) ${ }^{2,5-8)}$. Hence, the current scenario demands a chlorine-free substance for cooling applications.

In Japan, the annual electricity consumption of each house for cooling and heating purposes is approximately 0.7 and $1.2 \mathrm{GWh}$, respectively ${ }^{9)}$. The electricity used for operating the air-conditioning unit primarily comes from fossil-fuel based power plants ${ }^{10)}$. The fossil-fuel based power plants are accountable to free global warming gases ${ }^{11)}$. According to the World Bank, $\mathrm{CO}_{2}$ emission of Japan was 9.5 metric tons per capita until $2014{ }^{12)}$. The statistics of per capita $\mathrm{CO}_{2}$ equivalent emission is estimated to be $1.1 \mathrm{t} / \mathrm{year}$ globally, which can be reduced by harvesting sustainable energy such as fuel/ hydrogen cell ${ }^{13-15)}$. For the use of the clean fuel based residential and commercial air conditioning system, assessing the environmental impacts of the current refrigeration system is inevitable. Refrigerant leakage is a serious source of emissions in the case of the household air conditioning systems. The refrigerant 
leakage has a direct impact on global warming ${ }^{16,17)}$.

To minimize the global warming impact and reduce energy consumption, several refrigerants have the potentiality. Among those refrigerants: R134a, R32 and $\mathrm{R} 410 \mathrm{~A}$ refrigerants have been assessed. R410A and $\mathrm{R} 134 \mathrm{a}$ are chosen for the assessment because those are used in most of the household and office buildings cooling systems. Moreover, R32 refrigerant is recently invented and has the minimum GWP (675) among these three refrigerants ${ }^{4)}$. On the other hand, thermodynamic properties of R32, R134a and R410a are different. Hence, coefficient of performance (COP), leakage rate, and other important parameters are also different which have a significant impact on TEWI ${ }^{4,17,18)}$. According to these reports, we calculate the total equivalent warming impact for R134a, R32 and R410A refrigerants, respectively.

\section{Assessment Procedure}

\subsection{System Description}

A schematic of a typical household cooling system is shown in Fig. 1. In the cooling system, the refrigerant evaporates and boils inside the evaporator and changes from the liquid phase to the gas phase. During the phase change, it collects latent heat from the surroundings and cools the space. This vaporized refrigerant flows through the compressor for compression at high pressure. Hot and high pressure vapor refrigerant discharges from the compressor discharge line and feeds into the condenser coil. The hot gaseous refrigerant releases the heat to the air and changes to liquid. The discharged refrigerant at the output of the condenser is high-pressure liquid. This high-pressure refrigerant flows through the expansion valve and reaches to the evaporator coil again and the refrigeration cycle repeats until it reaches to the target temperature ${ }^{19)}$.
The term "Total equivalent warming impact (TEWI)" is used to express contributions to global warming. TEWI facilitate to estimate the equivalent greenhouse gases emissions into the atmosphere from system leakage (direct emission) and energy consumption (indirect emission). The TEWI is represented by the summation of the direct and indirect discharged greenhouse gases from the system.

Total equivalent warming impact can be summarized by the following equation ${ }^{26}$.

$$
T E W I=\underbrace{(G W P \times L R \times n)}_{\text {Direct }}+\underbrace{\left(E_{a} \times \beta \times n\right)}_{\text {Indirect }}
$$

GWP : Global warming potential of the selected refrigerants ( $\mathrm{kg} \mathrm{CO}_{2}$ eq/year)

$L R \quad: \quad$ Annual leakage rate (\%)

$n \quad:$ Number of years

$E_{a} \quad: \quad$ Annual electricity consumption (kWh)

$\beta \quad: \quad \mathrm{CO}_{2}$ emission factor for per $\mathrm{kW}$ electricity generation $(\mathrm{kg} \mathrm{CO} 2 \mathrm{eq})$

\subsection{Assumptions}

Operating conditions and relevant assumptions for household/ office cooling systems are shown in Table 1. The cooling load has been considered $5 \mathrm{~kW}$ for residential air-conditioning system because a typical sized-room can be cooled with that cooling capacity.

In summer, a typical outdoor temperature between 30 to $35^{\circ} \mathrm{C}$. Hence, the condensation temperature is usually considered $5-10^{\circ} \mathrm{C}$ higher than the typical outdoor temperature so that the refrigerants can release heat. For simplifying the assessment, a constant condensation temperature of $40{ }^{\circ} \mathrm{C}$ is considered in this analysis.

\subsection{TEWI Definition}

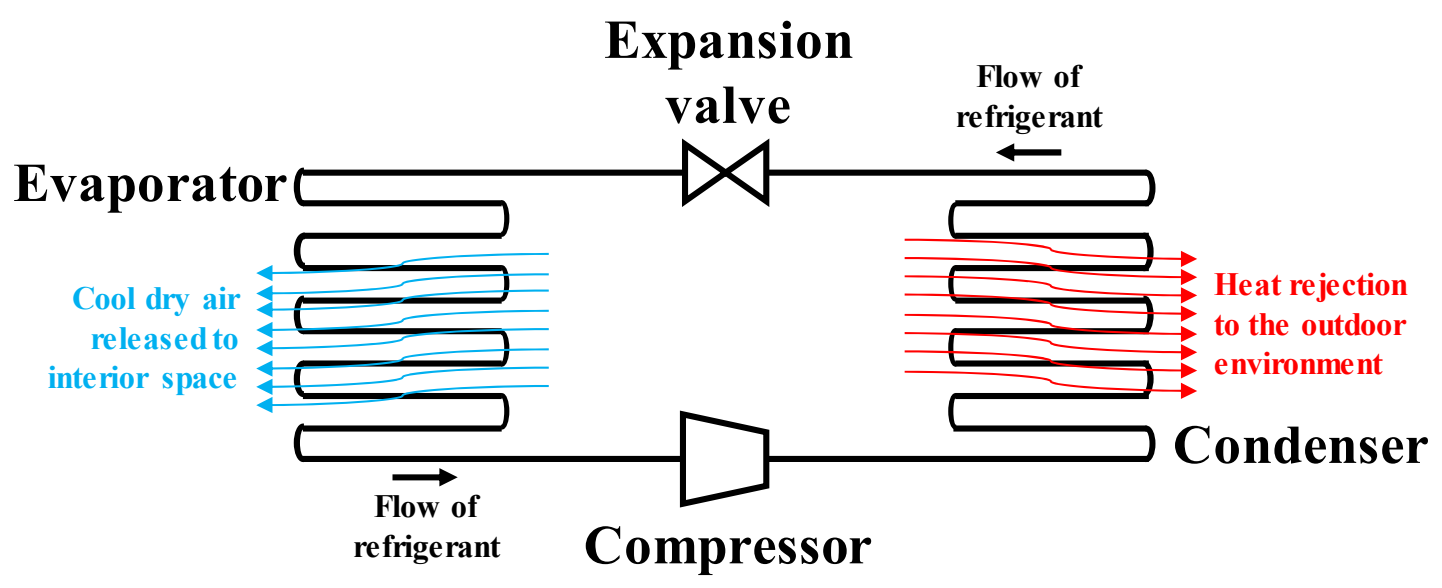

Fig. 1: Simplified schematic diagram of a household air-conditioning system. 
Generally, residential air-conditioning system usage is higher in weekends than working days. Besides, commercial air-conditioning is barely used in the holidays. Hence, the usage is 56 hours per week for a residential system and 40 hours for commercial office buildings.

The refrigerants R134a and R32 are commonly used in the residential systems. Whereas, R410A is deployed as a working fluid for heavy usage such as central airconditioning system in commercial buildings. Hence, these three refrigerants are selected for the current analysis.

Leakage of refrigerants usually depend on the operating conditions, specially the discharge pressure of the refrigerant from compressor outlet. Leakage rates of the selected refrigerants are assumed according to the thermodynamic property in the operating region.

Electricity production sources in Japan is mainly fossil fuel based which emits $0.56 \mathrm{~kg} \mathrm{CO}$ for per $\mathrm{kWh}$ electricity generation.

Required amount of refrigerant for a system is dependent on the cooling capacity, evaporation temperature, types of refrigerants and so on. However, for simplicity we considered initial charging amount is $1 \mathrm{~kg}$ of refrigerants for per $\mathrm{kW}$ cooling load.

Table 1. Conditions for TEWI assessment.

\begin{tabular}{|c|c|}
\hline $\begin{array}{l}\text { Cooling load (at } T_{\text {eva }}= \\
15^{\circ} \mathrm{C} \text { ) }\end{array}$ & $5 \mathrm{~kW}$ \\
\hline $\begin{array}{l}\text { Condensation } \\
\text { temperature }\left(T_{\text {con }}\right)\end{array}$ & $40^{\circ} \mathrm{C}$ \\
\hline Suction gas superheat & $5 \mathrm{~K}$ \\
\hline Liquid subcooling & $3 \mathrm{~K}$ \\
\hline Operation Time & $\begin{array}{l}56 \mathrm{hrs} / \text { week (residential) } \\
40 \mathrm{hrs} / \text { week } \\
\text { (commercial) }\end{array}$ \\
\hline Refrigerants & R134a, R32 and R410A \\
\hline $\begin{array}{l}\mathrm{GWP} \text { values of the } \\
\text { refrigerants }(\mathrm{kg} \mathrm{CO} 2 \\
\text { eq } / \mathrm{kg})\end{array}$ & $\begin{array}{l}\text { R134a: } 1430 \\
\text { R32: } 675 ; \\
\text { R410A: } 2088^{6) 20)}\end{array}$ \\
\hline Annual leakage rate & $\begin{array}{l}\text { R134a: } 12 \% ; \\
\text { R32: } 15 \% ; \\
\text { R410A: } 20 \%{ }^{21)} \text {.of } I^{a}\end{array}$ \\
\hline $\begin{array}{l}\text { GWP for electricity } \\
\text { production in Japan }\end{array}$ & $\begin{array}{l}0.56 \\
22,23)\end{array}$ \\
\hline $\begin{array}{l}\text { Initial refrigerant } \\
\text { charging amount }(\mathrm{kg} \\
\text { per } \mathrm{kW} \text { cooling load) }\end{array}$ & $1 \mathrm{~kg}^{24)}$ \\
\hline Refrigerant price $(\$ / \mathrm{kg})$ & $\begin{array}{l}\mathrm{R} 134 \mathrm{a}-22 \$ / \mathrm{kg}^{18)} \\
\mathrm{R} 32-24 \$ / \mathrm{kg}, \mathrm{R} 410 \mathrm{~A}- \\
15 \$ / \mathrm{kg}^{25)}\end{array}$ \\
\hline${ }^{\mathrm{a}} \mathrm{IC}$ : Initial charge & \\
\hline
\end{tabular}

The price of the selected refrigerants is obtained from the refrigerant manufacturers to estimate the economic loss due to refrigerant leakage from the system.

\subsection{Assessment of TEWI}

From the definitions of TEWI, the estimation of the co-efficient of performance (COP), the indirect and direct emissions for the several refrigerants R134a, R32, R410A, are explained below:

\subsubsection{Co-efficient of performance (COP)}

The performance of the air-conditioning system is expressed by COP,

$C O P=\frac{\text { Cooling capacity }}{\text { Work input or electricity consumpiton }}$

\subsubsection{Direct emission}

The direct release of the GHG gases to the atmosphere from the different equipment and processes are the direct emissions. Leakage of the refrigerant is the prime source of the direct emission considering household airconditioning system ${ }^{26)}$. Refrigerant leakage might happen during the manufacturing process, when in operation or during the maintenance and servicing. Earlier literature reported that about $10-20 \%$ refrigerant is leaked and refilled every year ${ }^{21)}$. Moreover, the type of refrigerant and operating conditions influences the leakage rate ${ }^{18,21,27)}$. The leakage rate for particular refrigerant and initially charged amount of refrigerant can be used for the calculation of direct emissions by using the equation (1).

\subsubsection{Indirect emission}

In an air-conditioning system, the compressor efficiency, system design, thermodynamic transport and heat-transfer properties of the refrigerant could affect the overall performance of the system. Indirect emission is a function of the efficiency of any parts of the entire system. Indirect emission might cause a greater effect on TEWI compared to direct emission ${ }^{6)}$.

The indirect emissions of the R134a, R32 and R410A, are calculated from the $\mathrm{P}-\mathrm{h}$ refrigeration cycles of specific air-conditioning system (Fig. 2). The refrigerant's thermodynamic properties are obtained from the REFPROP v.9.1 ${ }^{28)}$. In general, the airconditioning system has the superheating and the subcooling phase to compress the vapour and to evade the refrigerant flashing. The COP of the refrigeration system can be determined from the refrigeration cycle of Fig. 2 . 

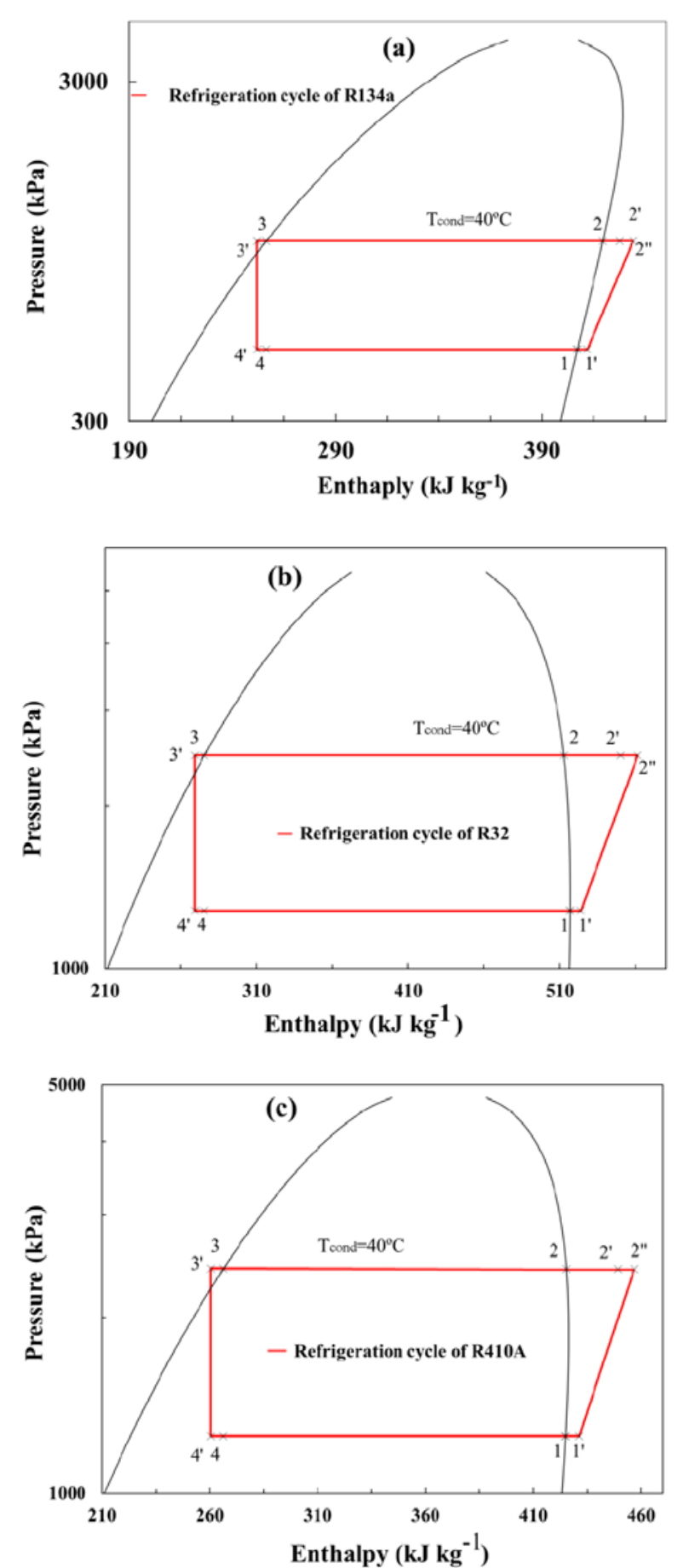

Fig. 2: P-h diagram of the refrigeration cycles for (a) R134a, (b) R32 and (c) R410A with suction superheating and liquid subcooling. 4'-1: evaporation; 11': suction superheating; 1'-2": compression; 2"-3 condensation; 3-3': liquid subcooling; 3'-4': expansion.

\section{Results \& Discussions}

\subsection{Direct emission}

Annual direct emission is dependent on the leakage of refrigerant, which is shown in Fig. 3. The direct emission for R134a, R32 and R410A is $0.86,0.51$ and $2.09 \mathrm{t}$ eq $\mathrm{CO}_{2} /$ year, respectively. Among these refrigerants, the R410A has a significantly higher environmental impact due to its high GWP value.

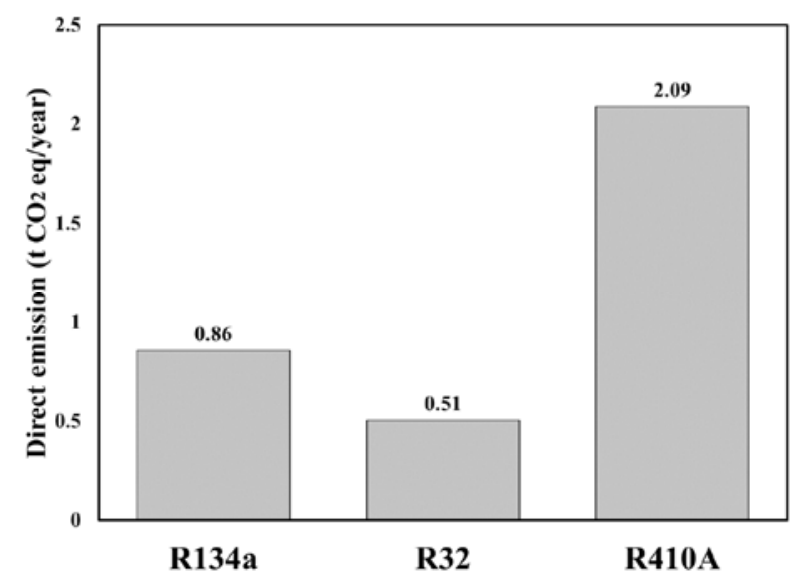

Fig. 3: Annual direct warming impact for different refrigerants.

\subsection{Indirect emission}

We have considered a cooling capacity of $5 \mathrm{~kW}$ and evaluated $\mathrm{COP}$ for each working fluid. COP values are compared in Fig. 4, which clearly indicate that the R134a system has the best performance. These COP values are used to assess electricity consumption and indirect emissions which are presented in Fig. 5. Annual indirect emission is evaluated for all the systems. The R134a showed the minimum indirect warming impact as compared to R410A and R32.

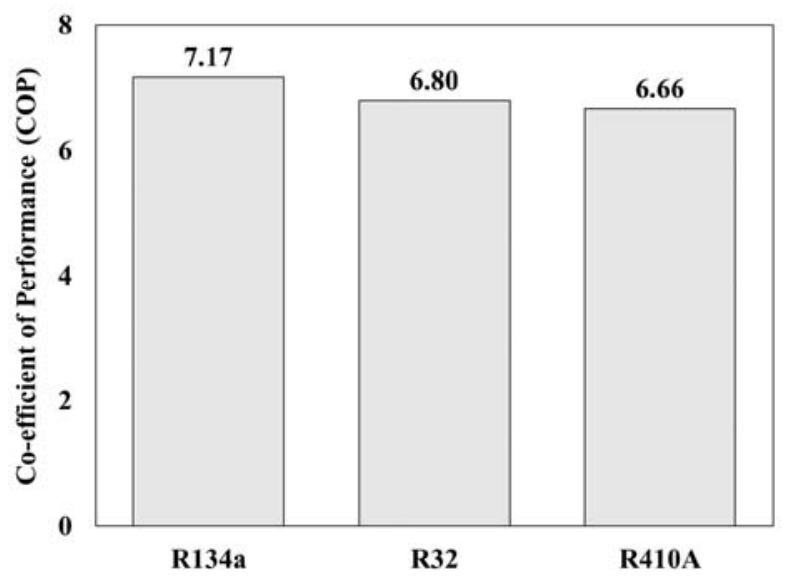

Fig. 4: COP value for HFC based refrigerants

\subsection{TEWI}

TEWI for the residential and commercial airconditioning system has been assessed by aggregating direct and indirect emissions which are shown in Fig. 6. In both cases, R410A has the highest TEWI compared 
to $\mathrm{R} 134 \mathrm{a}$ and $\mathrm{R} 32$. The result shows TEWI of the R134a and $\mathrm{R} 32$ are in the range of $1-2 \mathrm{t}$ eq $\mathrm{CO}_{2}$ /year for the commercial and residential air-conditioning system. The high GWP value of R410A accountable for higher TEWI.

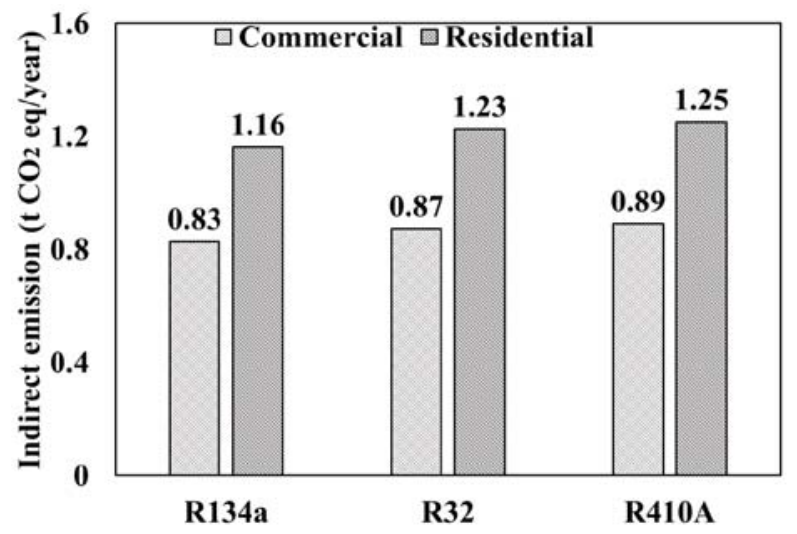

Fig. 5. Annual indirect warming impact for different refrigerants.

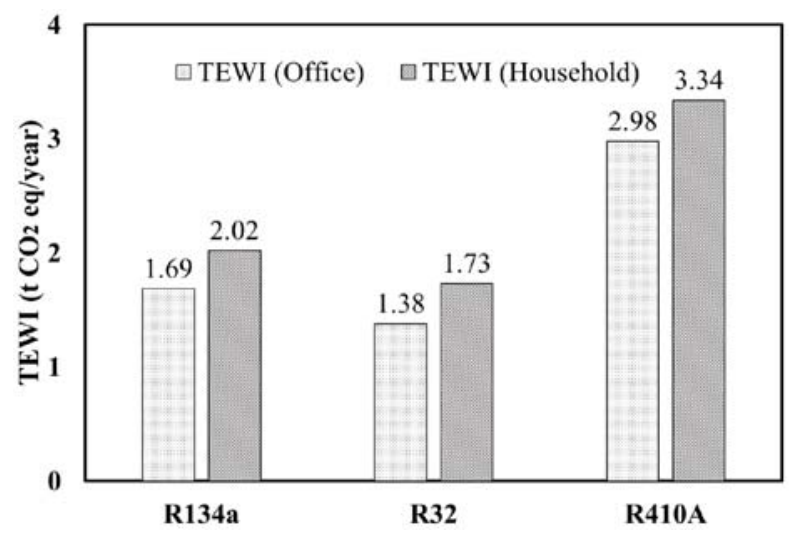

Fig. 6: Annual total equivalent warming impact for different refrigerants considering the individual airconditioning system.

\subsection{Economic loss}

A certain percentage of the charged refrigerant is leaked every year and that amount needs to be refilled for uninterrupted operation of the cooling system. This refill amount is accounted for the economic loss every year. The economic loss is estimated considering the one unit with the cooling capacity of $5 \mathrm{~kW}$. The refrigerant leakage is compared in Fig. 7 using R134a, R32, R410A.

According to the results, employing R134a as a refrigerant in the residential air-conditioning system might give a minimum economic loss compared to R32 and R410A refrigerants. The price and the annual leakage rate of the refrigerants affects the economic loss.

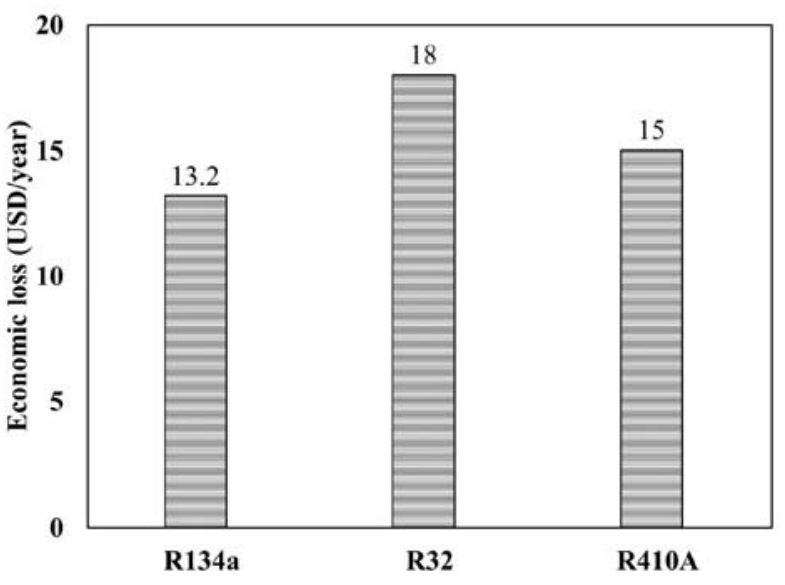

Fig. 7: Economic loss of individual air-conditioning system for R134a, R32 and R410A refrigerants.

\subsection{Effects of leakage rate on direct emission, TEWI and economic loss}

Direct emission is explicitly dependent on refrigerant leakage. In the analysis above, the leakage rate has been considered $12 \%, 15 \%$ and $20 \%$ for R134a, R32 and R410A, respectively. However, the actual leakage amount could vary. Hence, two other sets of leakage rate have been considered to observe the sensitivity of direct emission and TEWI with leakage rate. The result of the analysis is shown in Fig. 8. It can be seen that a $7 \%$ reduction of the leakage rate results in the reduction of $0.5 \mathrm{t} \mathrm{CO}_{2} \mathrm{eq} /$ year for R134a refrigerant. On the other hand, $5 \%$ reduction of the leakage rate can reduce the total equivalent warming impact about $0.17 \mathrm{t} \mathrm{CO}_{2} \mathrm{eq} /$ year for R32 refrigerants and $0.52 \mathrm{t} \mathrm{CO}_{2} \mathrm{eq} /$ year for $\mathrm{R} 410 \mathrm{~A}$ refrigerants. The $\mathrm{R} 32$ refrigerant shows lowest TEWI change with compared to R134a and R410A. The variation in TEWI is due to the GWP values of the selected refrigerants.

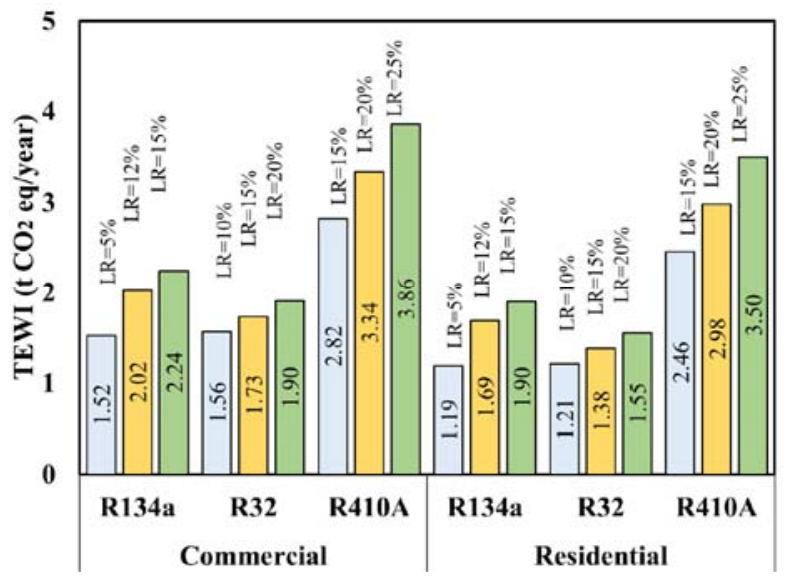

Fig. 8: Annual total equivalent warming impact for different refrigerants considering an individual airconditioning system for different leakage rate. 


\section{Indirect emission of different locations in Japan}

Indirect emissions at three major locations (Tokyo, Fukuoka and Hokkaido) of Japan have been estimated based on the electricity demand of those areas. These locations are selected due to their geographical locations and have a huge variation in weather and population density. Hokkaido is located in the north of Japan. Whereas, Tokyo is in the middle and Fukuoka is in the southern part of Japan. In 2014, Koyama et al. reported, Tokyo, Fukuoka and Hokkaido have the electricity demand of 4.67, 1.45, $1.03 \mathrm{GW}$, respectively. About $57 \%$ of this electricity is used for domestic airconditioning system ${ }^{3)}$. The indirect emissions of R134a, R32, and R410A refrigerants in Tokyo, Fukuoka and Hokkaido is presented in Fig. 9.

Evidently, the higher energy consumption for air conditioning system is responsible for higher indirect warming impact in the Tokyo region. The annual indirect emission in Fukuoka and Hokkaido is in the range of 150-350 kt $\mathrm{CO}_{2}$ eq. every year. On the other hand, indirect emission in Tokyo is four times higher than other two regions. Annual indirect emission in Tokyo considering R134a, R32 and R410A and as refrigerants are 774,833 and $817 \mathrm{kt} \mathrm{CO}_{2}$ eq., respectively for the commercial air-conditioning system. The similar trend can be observed in the residential air conditioning system where R410A has higher indirect emission compared with other refrigerants. In Tokyo, for commercial air conditioning system, selection of R134a refrigerants can reduce the indirect emission of $58 \mathrm{kt}$ $\mathrm{CO}_{2}$ eq/year.

\section{Conclusion}

TEWI assessments have been conducted for the airconditioning system (residential and commercial) by considering R134a, R32 and R410A as refrigerants. The results show that the R410A has a higher TEWI impact compared to R134a and R32 refrigerants. The LR (\%) variation has a significant impact on TEWI for R134a, R32 and R410A refrigerants. Decreasing of the leakage rate of the R134a, R32 and R410A refrigerants could give smaller TEWI for the residential and commercial air-conditioning system. Moreover, the leakage rate is responsible for the economic loss because the amount needs to be refilled for the smooth operation of the system. Since, the price of R32 is higher than R134a and $\mathrm{R} 410 \mathrm{~A}$, by using one of these refrigerants may give a higher economic profit compared to R32 refrigerant. Besides, a large indirect emission occurs in Tokyo compared to Fukuoka and Hokkaido due to higher airconditioning demand. Indirect emission in Tokyo is three times higher than in the other two cases. This TEWI estimation addresses significant evidence to the air-conditioning system manufacturer before choosing the refrigerant for a system.
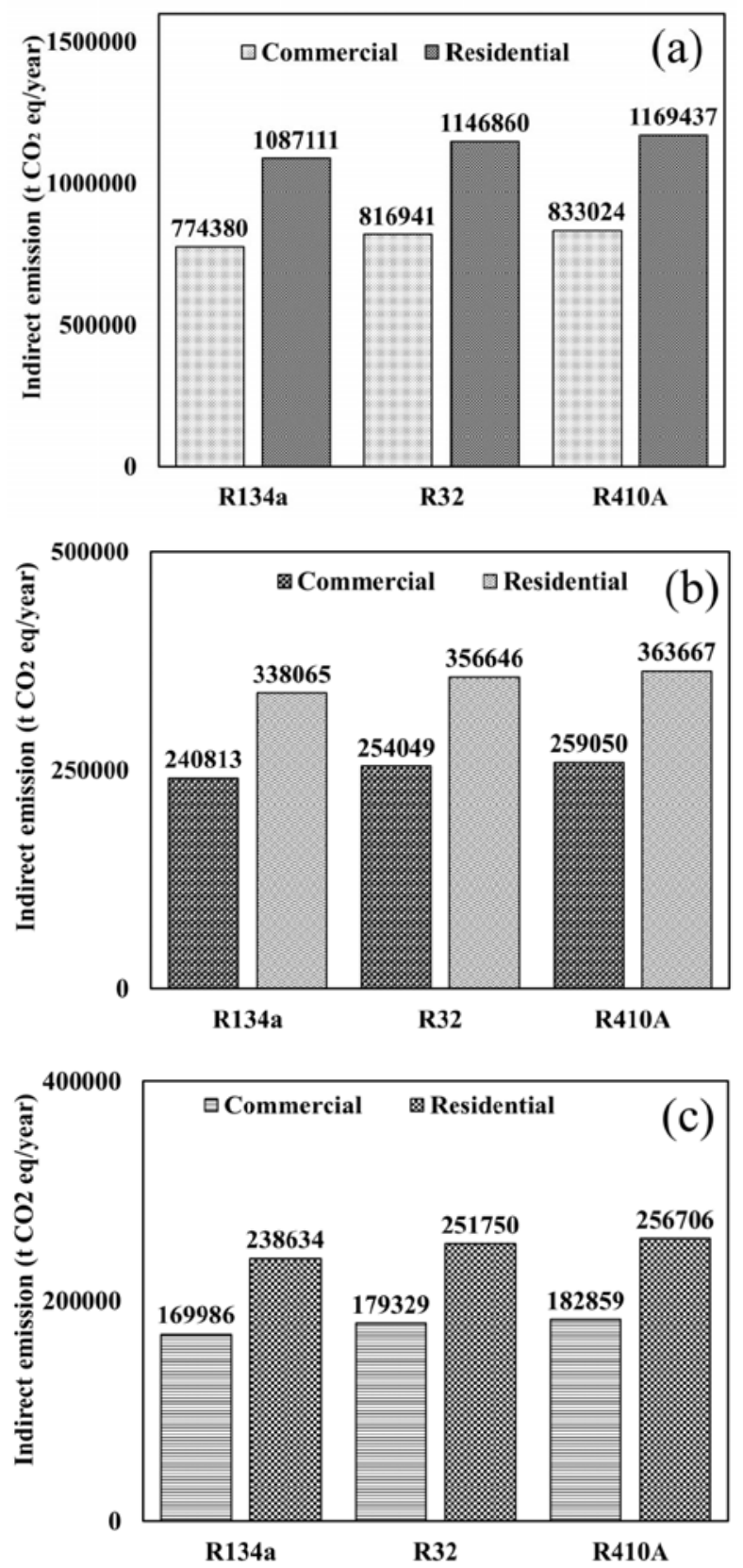

Fig. 9: Annual indirect emission of different refrigerants; (a) Tokyo; (b) Fukuoka; (c) Hokkaido.

\section{Acknowledgements}

This work was supported by the Advanced Graduate Program in Global Strategy for Green Asia (Kyushu University).

\section{References}

1) J. Yao, "Modelling and simulating occupant behaviour on air conditioning in residential buildings," Energy Build., 175 1-10 (2018). 
2) M.. Paridah, A. Moradbak, A.. Mohamed, F. abdulwahab taiwo Owolabi, M. Asniza, and S.H.. Abdul Khalid, "The impact on global warming of the substitution of refrigerant fluids in vapour compression plants: an experimental study," Intech, i (tourism) 13 (2016).

3) M. Koyama, S. Kimura, Y. Kikuchi, T. Nakagaki, and K. Itaoka, "Present status and points of discussion for future energy systems in japan from the aspects of technology options," J. Chem. Eng. Japan, 47 (7 SPECIAL ISSUE) 499-513 (2014).

4) B. Pavkovic, "Past, present and future perspectives of refrigerants in air-conditioning applications," REHVA J., (December) 28-33 (2013).

5) A. Pal, K. Uddin, K. Thu, and B.B. Saha, "Environmental assessment and characteristics of next generation refrigerants," Evergreen, 5 (2) 5866 (2018).

6) W. Beeton, B. Buynacek, and K. Monnier, "Refrigerants for Residential and Commercial Air Conditioning Applications," 2008. EmersonClimate.com.

7) I.I. El-Sharkawy, A. Pal, T. Miyazaki, B.B. Saha, and S. Koyama, "A study on consolidated composite adsorbents for cooling application," Appl. Therm. Eng., 98 1214-1220 (2016).

8) A. Pal, I.I. El-Sharkawy, B.B. Saha, S. Jribi, T. Miyazaki, and S. Koyama, "Experimental investigation of $\mathrm{co} 2$ adsorption onto a carbon based consolidated composite adsorbent for adsorption cooling application," Appl. Therm. Eng., 109 304-311 (2016).

9) I. Matsukawa, "Consumer Energy Conservation Behavior After Fukushima: Evidence from field experiments," in: S. in Economics (Ed.), Springer nature, 2016.

10) M.A. Alzoubi, and T. Zhang, "Characterization of Energy Efficient Vapor Compression Cycle Prototype with a Linear Compressor," in: Energy Procedia, Elsevier B.V., 2015: pp. 3253-3258.

11) A. Cherp, V. Vinichenko, J. Jewell, M. Suzuki, and M. Antal, "Comparing electricity transitions: a historical analysis of nuclear, wind and solar power in germany and japan," Energy Policy, 101 612628 (2017).

12) The World Bank, "World development indicators : energy dependency, efficiency and carbon dioxide emissions," (2017). http://wdi.worldbank.org/ table/3.8\#.

13) A. Kazim, "Strategy for a sustainable development in the uae through hydrogen energy," Renew. Energy, 35 (10) 2257-2269 (2010).

14) A.M. Kazim, "Assessments of primary energy consumption and its environmental consequences in the united arab emirates," Renew. Sustain. Energy Rev., 11 (3) 426-446 (2007).

15) M. Ball, and M. Weeda, "The hydrogen economy - vision or reality?11this paper is also published as chapter 11 'the hydrogen economy - vision or reality?' in compendium of hydrogen energy volume 4: hydrogen use, safety and the hydrogen economy, edited by michael ball, angelo basi," Int . J. Hydrogen Energy, 40 (25) 7903-7919 (2015).

16) Y.T. Ge, and S.A. Tassou, "Performance evaluation and optimal design of supermarket refrigeration systems with supermarket model 'supersim', part i: model description and validation," Int. J. Refrig., 34 (2) 527-539 (2011).

17) J.L. Gasche, T. Andreotti, and C.R.M.E. Maia, "A model to predict $\mathrm{r} 134 \mathrm{a}$ refrigerant leakage through the radial clearance of rolling piston compressors," Int. J. Refrig., 35 (8) 2223-2232 (2012).

18) M.A. Islam, K. Srinivasan, K. Thu, and B.B. Saha, "Assessment of total equivalent warming impact (tewi) of supermarket refrigeration systems," Int. J. Hydrogen Energy, 42 (43) 26973-26983 (2017).

19) T. Evans, "Fundamental Principles of Air Conditioners for Information Technology," West Kinston, 2008.

20) ACRIB, "2014 F-Gas Regulation and GWP Values," Wales, United Kingdom, 2015. www.acrib.org.uk.

21) D. Cowan, J. Gartshore, I. Chaer, C. Francis, and G. Maidment, "REAL Zero - Reducing refrigerant emissions \& leakage - feedback from the IOR Project," in: Proc. Inst. R., 2009: p. 16. https://www.epa.gov/sites/production/files/docum ents/IOR_ReducingRefrigerantEmissions.pdf.

22) S. Kohei, “Japan's Greenhouse Gas (GHG) Inventories and Related Activities," in: IPCC Open Symp., Green House Gas Inventory Office of Japan, 2013.

23) S. Katsuno, and A. Mayumi, "Electricity Review Japan," Tokyo, 2018.

24) F. Poggi, H. Macchi-Tejeda, D. Leducq, and A. Bontemps, "Refrigerant charge in refrigerating systems and strategies of charge reduction," Int. J. 
Refrig., 31 (3) 353-370 (2008).

25) Monotaro, "R410A fluorocarbon gas," 1-7 (2019). https://www.monotaro.com/g/01240160/?t.q=HF C\%97\%E2\%94\%7D R410A.

26) T. Grof, "Greening of Industry under the Montreal Protocol," Vienna, Austria, 2009. www.unido.org.

27) U.S. EPA Center for Corporate Climate Leadership, "Direct Fugitive Emissions from Refrigeration, Air Conditioning, Fire Suppression, and Industrial Gases," 2014. www.epa.gov/climateleadership.

28) M.O. Lemmon, E. W, Huber, M. L, Mclinden, "NIST standard reference database 23: reference fluid thermodynamic and transport properties (refprop), version 9.1," NIST Stand. Ref. Database 23 Ref. Fluid Thermodyn. Transp. Prop. (REFPROP), Version 9.1, (2013). 